\title{
EFFECTS OF CUTTING PARAMETERS AND TOOL-PATH STRATEGIES ON TOOL ACCELERATION IN BALL-END MILLING
}

\section{UČINKI REZALNIH PARAMETROV IN STRATEGIJA ZA POSPEŠEK ORODJA PRI MEHANSKI OBDELAVI S KROGLIČNIM FREZALOM}

\author{
Arif Gök¹, Kadir Gök², Mehmet Burak Bilgin', Mehmet Ali Alkan³ \\ ${ }^{1}$ Amasya University, Faculty of Technology, Department of Mechnical Engineering, 05100 Amasya, Turkey \\ ${ }^{2}$ Celal Bayar University, Favulty of Technology, Department of Mechanical and Manufacturing Engineering, 45100 Manisa, Turkey \\ ${ }^{3}$ Muğla Sitki Kocman University, Ula Vocational High School, Department of Energy, 48000 Mugla, Turkey \\ arif.gok@amasya.edu.tr
}

Prejem rokopisa - received: 2017-04-08; sprejem za objavo - accepted for publication: 2017-06-22

doi: $10.17222 / \mathrm{mit} .2017 .039$

\begin{abstract}
The determination of the cutting-parameter values that cause increases in vibration values is important to minimize the errors that can occur. Thus, the first aim of this study was to investigate the optimum cutting-parameter values and tool-path strategies in ball-end milling of the EN X40CrMoV5-1 tool steel with three coated cutters using the Taguchi method. The parameters taken into consideration are the cutting speed, feed rate, step over and tool-path strategies. The second aim of the study, a model for the tool acceleration as a function of the cutting parameters, was obtained using the response-surface methodology (RSM). As a result, the most effective parameter within the selected cutting parameters and cutting strategies for both inclined surfaces and different coatings was the step over. In terms of tool coatings, the most deteriorating coating for the tool acceleration on both inclined surfaces was the TiC coating. In addition, the response-surface methodology is employed to predict the tool-vibration values depending on the cutting parameters and tool-path strategy. The model generated gives highly accurate results.

Keywords: inclined surfaces, ball-end milling, tool acceleration, Taguchi method, response-surface methodology, response optimization
\end{abstract}

Neoptimalni rezalni parametri med mehansko obdelavo lahko povzročijo neželene vibracije in posledično napake. Prvi cilj avtorjev te študije je bil določiti optimalne vrednosti rezalnih parametrov in strategije potovanja orodja med mehansko obdelavo orodnega jekla EN X40CrMoV5-1 s krogličnim frezalom s tremi rezili z različno prevleko (TiC, TiN in TiAlN). Za to so uporabili Taguchi-jevo metodo. Parametri, ki so jih avtorji zajeli v študiji so bili: hitrost rezanja, velikost odvzema, korak odvzema (preskok) in strategija poti orodja. Drugi cilj avtorjev te študije je bil izdelati model pospeševanja orodja $\mathrm{v}$ odvisnosti od rezalnih parametrov, z uporabo metodologije odziva površine (angl. RSM). Ugotovili so, da je korak odvzema (angl.: step over) najučinkovitejši parameter med izbranimi rezalnimi parametri in rezalnimi strategijami, tako za oba izbrana nagiba (ukrivljenosti) površine, kot tudi izbrane trde prevleke. Med izbranimi trdimi prevlekami se je v vseh pogojih frezanja kot najslabša izkazala TiC prevleka. RSM metodologija dodatno omogoča napoved vibracij orodja v odvisnosti od rezalnih parametrov in izbrane strategije poti orodja. Izdelani model daje zelo točne rezultate.

Ključne besede: nagib (ukrivljenost) površine, mehanska obdelava s krogličnim frezalom, pospešek orodja, Taguchi metoda, metodologija odgovora površine, optimizacija odgovora

\section{INTRODUCTION}

Nowadays, machining is one of the most important methods for manufacturing technologies and it remains up-to-date. ${ }^{1}$ In the machining of inclined surfaces, tight machining tolerances are generally requested for the processes of finishing and semi-finishing, which are accomplished using indexable insert ball-end mills..$^{2,3}$ The forces that occur at high cutting speeds, especially during hard machining, and at high rates of metal removing, cause excessive, irregular vibrations of cutting tools during the machining. These vibrations cause the cutting tools to break, disrupting the process stability and the quality. Therefore, generating the optimum cutting parameters is crucial to obtain high productivity in the manufacturing process of complex geometries and to reach the desired tolerance values. ${ }^{4,5}$ The studies carried out in the field commonly focus on:
1) the effect of cutting parameters and cutting strategies of plain-surface milling,

2) analytical tool-acceleration calculations and measurements for end-milling and turning operations.

W. H. Yang and Y. S. Tarng ${ }^{6}$ worked on the optimization of the cutting parameters for turning operations so that both optimum cutting parameters were demonstrated and the basic cutting parameters affecting the cutting performance in turning were defined.

M. Kurt et al. $^{7}$ worked on the optimization of the cutting parameters for the finish surface and the accuracy of the hole diameter during dry drilling. In this way, optimum cutting conditions were obtained with the process optimization.

C. Gologlu and N. Sakarya ${ }^{8}$ investigated the effects of tool-path strategies on the surface roughness for pocket-milling operations using cutting parameters with 
different values. It was found that the most influential parameter for one-way and spiral tool-path strategies was the feed rate, and the depth of cut was the most important parameter for back-and-forth tool-path strategies. S. Neseli et al. ${ }^{9}$ worked on the optimization of the tool-geometry parameters for turning operations based on the response-surface methodology. In parallel to this study, Asilturk and Neseli ${ }^{10}$ worked on the multi-response optimization of CNC turning parameters via a Taguchi-method-based response-surface analysis. M. M. De Aguiar et al. ${ }^{11}$ investigated the correlating surface roughness, tool wear and tool vibration in the milling process of hardened steel using long slender tools. In this study, a good workpiece-surface roughness together with a long tool life of long tools with small diameters was achieved. H. Wang et al. ${ }^{12}$ worked on an investigation of the influence of the tool-tip vibration on the surface roughness and its representative measurement in ultraprecision diamond turning. This paper is dedicated to a study of the influence of the tool-tip vibration on the surface roughness. A. O. Abouelatta and J. Madl ${ }^{13}$ worked on the surface-roughness prediction based on the cutting parameters and tool vibrations in turning operations. S. Orhan et al. ${ }^{14}$ worked on the relationship between the vibration and the tool wear during end milling.

The studies given above were concentrated on the determination of the most appropriate parameters for the machining processes involving flat and inclined surfaces. However, the studies confirm that an aggregated effect of the cutting parameters and tool-path styles on the tool acceleration in inclined geometries (convex and concave) were not widely investigated. This study examines the

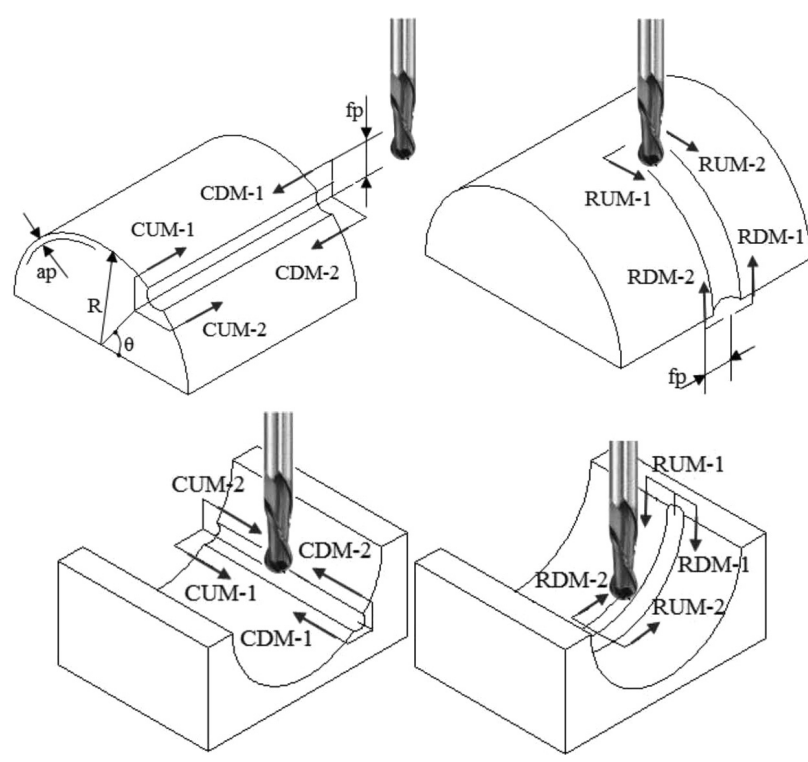

Figure 1: Inclined surfaces and related cutter path styles: CUM-1 (upward step over), CDM-1 (upward step over), CUM-2 (downward step over), CDM-2 (downward step over), RUM-1 (left step over), RDM-1 (left step over), RUM-2 (right step over), RDM-2 (right step over) effects of the cutting parameters and tool-path styles on the tool acceleration in the machining of convex and concave surfaces using ball-end mills. By doing so, it aims to keep the tool-acceleration values at a minimum, and to control the unwanted machining results such as poor surface quality and machining errors.

\subsection{Tool-path strategies and cutting parameters}

In the experimental studies, contouring and ramping tool-path styles are used to produce inclined surfaces. These tool-path styles can be established based on up-milling and down-milling strategies by making the movements of ramping and contouring. Ramping and contouring are inevitable choices of the tool-path styles for the implementation of the up-milling and downmilling strategies. ${ }^{5}$ In the ramping tool-path styles, the cutter scans an inclined surface following the lines in parallel to the surface radius. On the other hand, in the contouring tool-path styles, the cutter scans an inclined surface following the lines perpendicular to the surface radius. ${ }^{15-17}$ In this study, the step-over values are kept constant in both tool-path styles. After each step of the machining, the cutter moves one step sideways to the position, in which it returns back to the staring level of that step and then makes the next step. ${ }^{15}$ In the study under these conditions, four tool-path styles were generated: contouring up milling (CUM), contouring down milling (CDM), ramping up milling (RUM) and ramping down milling (RDM). The form radius of workpiece, milling position angle, nominal depth of cut, step over and spindle speed are indicated by $R, \theta, a_{\mathrm{p}}, f_{\mathrm{p}}$, and $S$, respectively (Figure 1).

In addition to the cutter path styles defined, three different variable parameters were used for semi-finishing operations. These were the cutting velocity $\left(V_{\mathrm{c}}\right)$, feed rate $\left(V_{\mathrm{f}}\right)$ and cutting step over $\left(f_{\mathrm{p}}\right)$. The cutting-velocity and feed-rate values were taken from the reference catalogues of the tool manufacturer (Sandvik Company). In order to determine the right cutting-tool values (Table 1), a number of experiments for each tool coating was conducted based on the reference values. ${ }^{5}$ The cutting-

Table 1: Assignment of the levels to factors

\begin{tabular}{|c|c|c|c|c|c|}
\hline Factors & & Level 1 & Level 2 & Level 3 & Level 4 \\
\hline \multirow{3}{*}{$\begin{array}{c}\text { Cutting } \\
\text { velocity, } \\
V_{\mathrm{c}}(\mathrm{m} / \mathrm{min})- \\
\mathrm{A}\end{array}$} & $\mathrm{TiC}$ & 70 & 80 & 90 & 100 \\
\hline & $\mathrm{TiN}$ & 100 & 110 & 120 & 130 \\
\hline & TiAlN & 110 & 120 & 130 & 140 \\
\hline \multirow{3}{*}{$\begin{array}{c}\text { Feed rate, } \\
V_{\mathrm{f}}(\mathrm{mm} / \mathrm{rev})- \\
\mathrm{B}\end{array}$} & $\mathrm{TiC}$ & 223 & 255 & 286 & 318 \\
\hline & $\mathrm{TiN}$ & 318 & 350 & 382 & 414 \\
\hline & TiAlN & 350 & 382 & 414 & 445 \\
\hline $\begin{array}{l}\text { Step over, } f_{\mathrm{p}} \\
(\mathrm{mm})-\mathrm{C}\end{array}$ & & 0.8 & 1 & 1.5 & 2 \\
\hline $\begin{array}{l}\text { Cutting path } \\
\text { styles - D }\end{array}$ & & $\begin{array}{l}\text { Contour- } \\
\text { ing up } \\
\text { milling } \\
\text { (CUM) }\end{array}$ & $\begin{array}{c}\text { Contour- } \\
\text { ing down } \\
\text { milling } \\
(\mathrm{CDM})\end{array}$ & $\begin{array}{l}\text { Ramping } \\
\text { up } \\
\text { milling } \\
\text { (RUM) }\end{array}$ & $\begin{array}{l}\text { Ramping } \\
\text { down } \\
\text { milling } \\
\text { (RDM) }\end{array}$ \\
\hline
\end{tabular}


A. GÖK et al.: EFFECTS OF CUTTING PARAMETERS AND TOOL-PATH STRATEGIES ON TOOL ACCELERATION ...

tool step-over values directly affect the tracks on the surface made by the cutter, the load on the cutter and processing time. ${ }^{8}$ The step-over value was chosen to be $5 \%$ of the tool diameter and this value was set as the lower level of $f p$. The depth of cut was taken as $0.3 \mathrm{~mm}$ and fixed as a constant. An orthogonal array of $L$ ' 16 was chosen for the experimental design and four different levels were defined for each cutting parameter (Table 1).

\section{EXPERIMENTAL PART}

The EN X40CrMoV5-1 hot-work tool steel was selected for the study. The material is commonly used in tool-making processes due to the quality characteristics including high durability, high thermal conductivity, high machinability and high cracking resistance. ${ }^{5}$ First, experimental samples of $(40 \times 30) \mathrm{mm}$ islands on a $(220$ $\times 135 \times 50) \mathrm{mm}$ block were machined. In the experiments, an indexable cutter body of an $\varnothing 16 \mathrm{~mm}$ cylindrical shank (CoroMill, R216-16A20-045) with a twofluted $30^{\circ}$-helix-angle end mill was used. The ball-end inserts of TiC, TiN and TiAlN coated with 3- $\mu \mathrm{m}$ R216-16 03 M-M H13A were used. Semi-finishing operations were employed and no coolant was used in the machining. The experiments were carried out on a vertical machining center of a John Ford VMC 550, with $12000 \mathrm{~min}^{-1}$ and a 12-kW engine. The experimental set-up is shown in Figure 2. The acceleration of the vibration signals generated during the cutting was measured using a piezoelectric accelerometer (VibroTest 60) based on the ISO 2954 standard. The accelerometer was mounted on the workpiece via a magnetization feature.

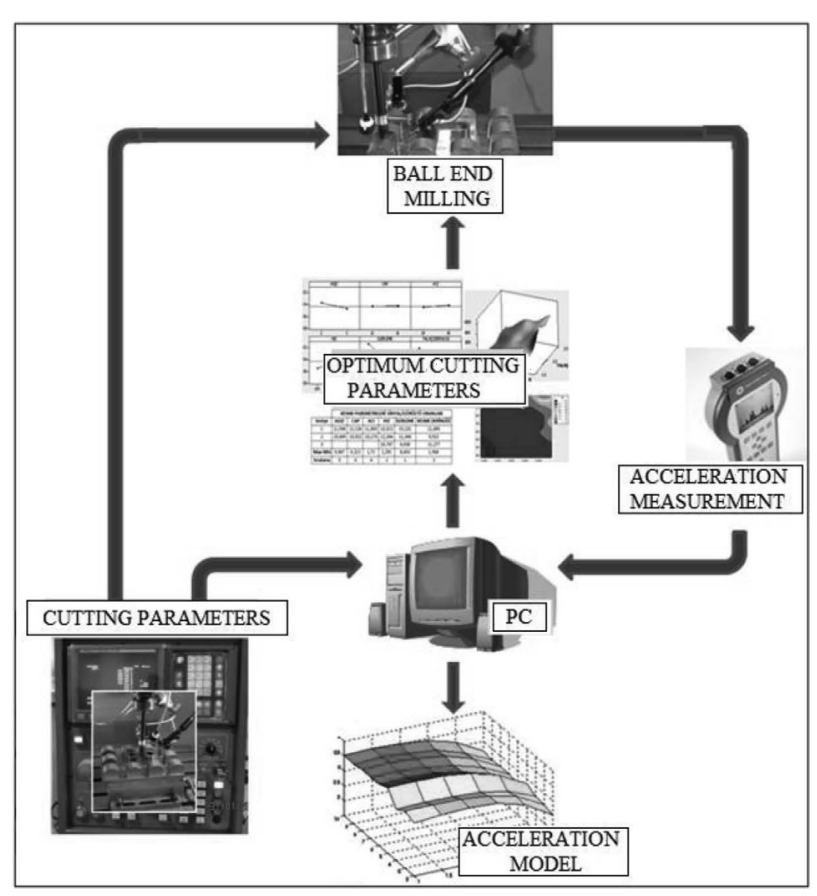

Figure 2: Experimental set-up

\subsection{Tool acceleration}

Tool acceleration occurs in machining operations due to the interaction between the tool and workpiece structure. Each tooth pass leaves a modulated surface on the workpiece due to the vibrations of the tool and workpiece, causing a variation in the expected chip thickness. Under certain cutting conditions (i.e., feed rate, depth of cut and cutting velocity), significant chip-thickness variations, and hence force and displacement variations, occur and a vibration is present. ${ }^{18}$ Vibrations result in a poor surface finish, excessive tool wear, reduced dimensional accuracy and tool damage. For a milling process, conservative cutting conditions are usually selected to avoid vibrations that decrease productivity. ${ }^{19}$

The values of the tool acceleration were experimentally measured during the machining of inclined surfaces (Table 2).

Table 2: Measured values of tool acceleration

\begin{tabular}{|c|c|c|c|c|c|c|}
\hline \multirow[b]{2}{*}{$\begin{array}{l}\text { Exp. } \\
\text { No. }\end{array}$} & \multicolumn{3}{|c|}{ Convex inclined surface } & \multicolumn{3}{|c|}{ Concave inclined surface } \\
\hline & $\begin{array}{l}\left(\mathrm{m} / \mathrm{s}^{2}\right. \\
\text { peak) } \\
(\mathrm{TiC})\end{array}$ & $\begin{array}{l}\left(\mathrm{m} / \mathrm{s}^{2}\right. \\
\text { peak }) \\
(\mathrm{TiN})\end{array}$ & $\begin{array}{l}\left(\mathrm{m} / \mathrm{s}^{2}\right. \\
\text { peak }) \\
(\mathrm{TiAlN})\end{array}$ & $\begin{array}{l}\left(\mathrm{m} / \mathrm{s}^{2}\right. \\
\mathrm{peak}) \\
(\mathrm{TiC})\end{array}$ & $\begin{array}{l}\left(\mathrm{m} / \mathrm{s}^{2}\right. \\
\text { peak) } \\
(\mathrm{TiN})\end{array}$ & $\begin{array}{c}\left(\mathrm{m} / \mathrm{s}^{2}\right. \\
\text { peak }) \\
(\text { TiAlN) }\end{array}$ \\
\hline 1 & 0.125 & 0.117 & 0.103 & 0.287 & 0.254 & 0.241 \\
\hline 2 & 0.197 & 0.189 & 0.214 & 0.428 & 0.277 & 0.358 \\
\hline 3 & 0.205 & 0.216 & 0.235 & 0.501 & 0.411 & 0.383 \\
\hline 4 & 0.292 & 0.239 & 0.286 & 0.637 & 0.471 & 0.465 \\
\hline 5 & 0.137 & 0.154 & 0.149 & 0.356 & 0.346 & 0.326 \\
\hline 6 & 0.145 & 0.167 & 0.195 & 0.311 & 0.265 & 0.275 \\
\hline 7 & 0.261 & 0.217 & 0.277 & 0.556 & 0.456 & 0.411 \\
\hline 8 & 0.253 & 0.206 & 0.218 & 0.477 & 0.461 & 0.437 \\
\hline 9 & 0.210 & 0.196 & 0.174 & 0.389 & 0.379 & 0.325 \\
\hline 10 & 0.249 & 0.247 & 0.219 & 0.461 & 0.381 & 0.375 \\
\hline 11 & 0.174 & 0.162 & 0.189 & 0.292 & 0.260 & 0.317 \\
\hline 12 & 0.181 & 0.187 & 0.228 & 0.481 & 0.398 & 0.263 \\
\hline 13 & 0.191 & 0.175 & 0.182 & 0.447 & 0.417 & 0.445 \\
\hline 14 & 0.131 & 0.186 & 0.197 & 0.345 & 0.357 & 0.281 \\
\hline 15 & 0.138 & 0.135 & 0.130 & 0.308 & 0.293 & 0.279 \\
\hline 16 & 0.129 & 0.127 & 0.128 & 0.297 & 0.259 & 0.254 \\
\hline
\end{tabular}

The orthogonal array chosen was $L 16\left(4^{4}\right)$, with 16 rows corresponding to the number of experiments (4 factors with 4 levels each). To obtain the optimum cutting performance, the smaller-the-better quality characteristic for the tool acceleration was adopted. The $S / N$ ratio was defined as follows in Equation (1):

$$
\frac{S}{N}=-10 \lg \frac{1}{N} \sum_{i=1}^{n} Y_{i}^{2}
$$

where $Y_{i}$ is the observed data at the $i$ th experiment and $n$ is the number of experiments.

\subsection{Response-surface methodology}

The response surface methodology (RSM) is a well-known up-to-date approach to the optimization of input-parameter models based on either physical or simulation experiments and experimental observations. 


\section{MATERIALI IN TEHNOLOGIJE/MATERIALS AND TECHNOLOGY (1967-2017) - 50 LET/50 YEARS}

A. GÖK et al.: EFFECTS OF CUTTING PARAMETERS AND TOOL-PATH STRATEGIES ON TOOL ACCELERATION ...

These approximated models need to be assessed statistically for their adequacy, and then they can be utilized for an optimization of the initial model. ${ }^{10}$ Response-surface-methodology problems follow a functional relation between responses and independent variables, and this relation can be explained using the second-order polynomial model in Equation (2): ${ }^{20}$

$$
\eta=\beta_{0}+\sum_{i=1}^{k} \beta_{i} X_{1}+\sum_{i=1}^{k} \beta_{i i} X_{i}^{2}+\sum_{i} \sum_{j} \beta_{i i} X_{i} X_{j}+\varepsilon
$$

where $\eta$ is the estimated response (the tool acceleration); $\beta_{0}$ is the constant; $\beta i, \beta i i$ and $\beta i j$ represent the coefficients of linear, quadratic and cross-product terms, respectively. $X$ reveals the coded variables.

\section{RESULTS}

The $S / N$ ratios of the four factors from Equation (1) were calculated for each of the tool coatings, and convex and concave inclined surface types (Figures 3 to 8 ). The largest $S / N$ ratios always yield the optimum quality with the minimum variance. ${ }^{5}$ Therefore, the level with the largest value determines the optimum level of each factor. From Figures 3 and $\mathbf{4}$, relating to the milling of the TiC-coated convex and concave inclined surfaces, the optimum levels in terms of the tool acceleration can be

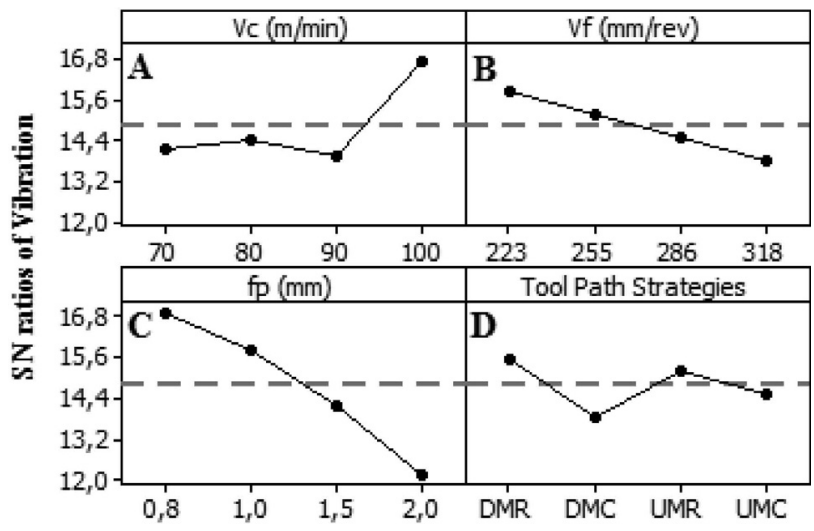

Figure 3: $S / N$ ratios for milling a TiC-coated convex inclined surface

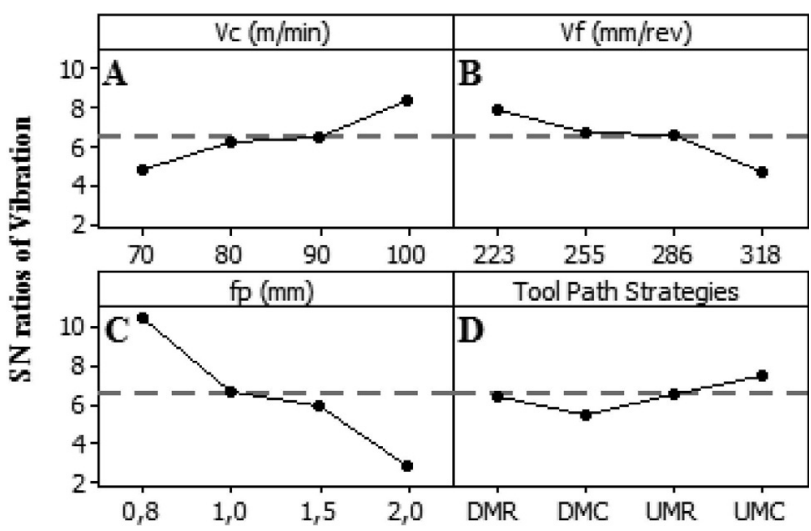

Figure 4: $S / N$ ratios for milling a TiC-coated concave inclined surface observed at A4 for $V_{\mathrm{c}}(100 \mathrm{~m} / \mathrm{min}), \mathrm{B} 1$ for $V_{\mathrm{f}}\left(223 \mathrm{~min}^{-1}\right)$ and $\mathrm{C} 1$ for $f_{\mathrm{p}}(0.8 \mathrm{~mm})$. For the tool-path styles, the optimum levels can be observed at D4 (UMC) for the convex inclined surface and D1 (DMR) for the concave inclined surface. From Figures 5 and $\mathbf{6}$, relating to the milling of the TiN-coated convex and concave inclined surfaces, the optimum levels in terms of the tool acceleration can be observed at $\mathrm{A} 4$ for $V_{\mathrm{c}}(130 \mathrm{~m} / \mathrm{min}), \mathrm{B} 1$ for $V_{\mathrm{f}}$ $\left(318 \mathrm{~min}^{-1}\right), \mathrm{C} 1$ for $f_{\mathrm{p}}(0.8 \mathrm{~mm})$ and $\mathrm{D} 1$ (DMR) for the

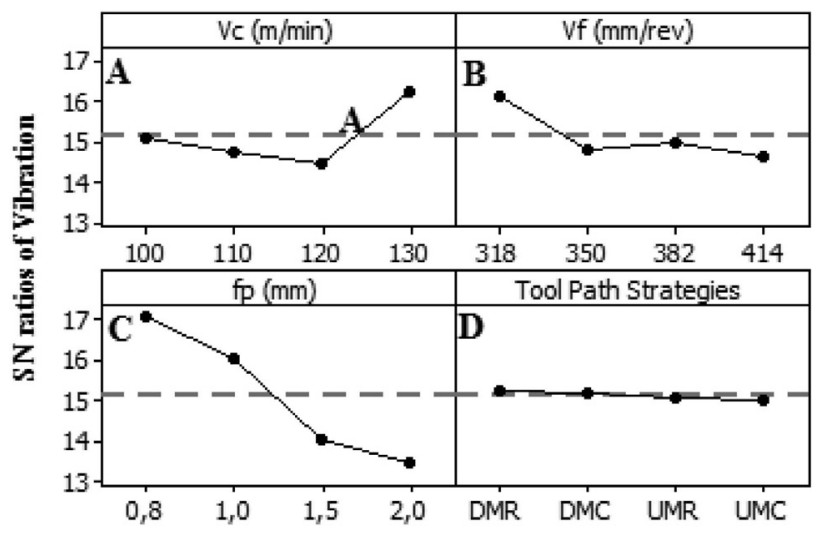

Figure 5: $S / N$ ratios for milling a TiN-coated convex inclined surface

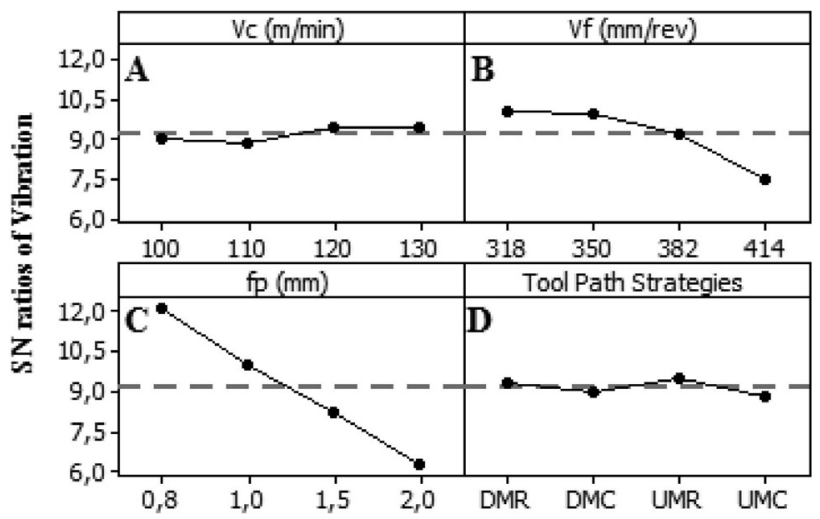

Figure 6: $S / N$ ratios for milling a TiN-coated concave inclined surface

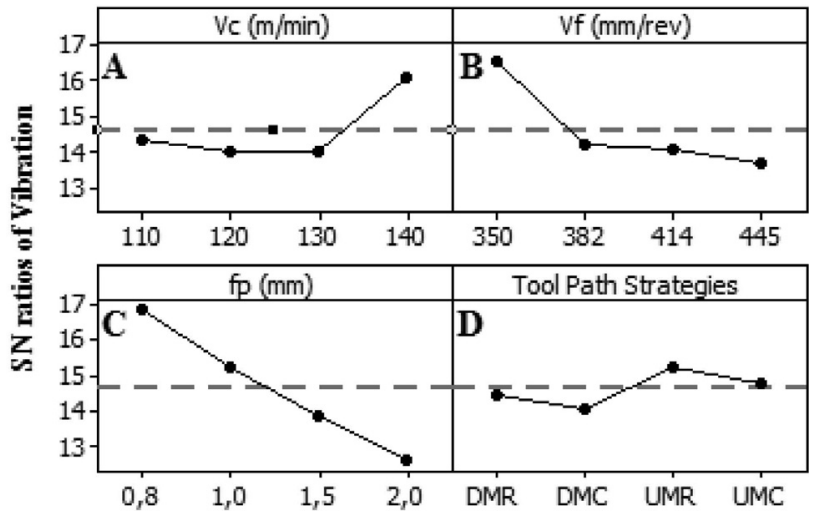

Figure 7: $S / N$ ratios for milling convex inclined surfaces with a TiAlN-coated cutter 


\section{MATERIALI IN TEHNOLOGIJE/MATERIALS AND TECHNOLOGY (1967-2017) - 50 LET/50 YEARS}

A. GÖK et al.: EFFECTS OF CUTTING PARAMETERS AND TOOL-PATH STRATEGIES ON TOOL ACCELERATION ...

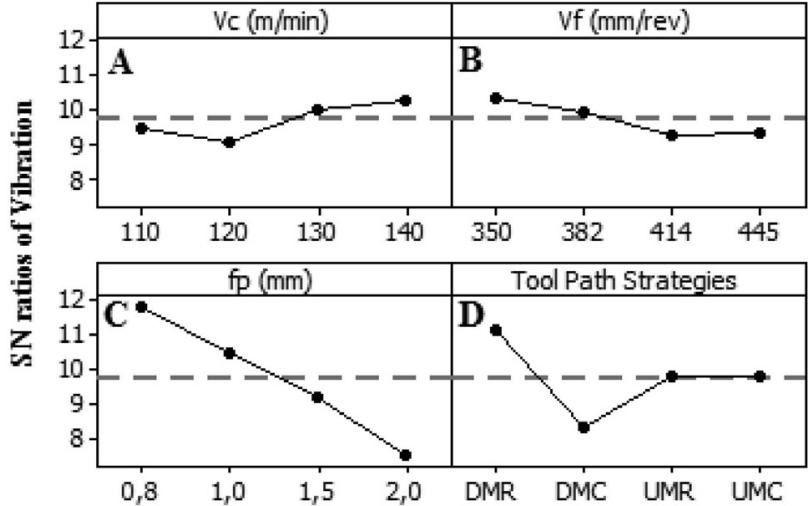

Figure 8: $S / N$ ratios for milling a TiAlN-coated concave inclined surface tool-path style. Likewise, from Figures 7 and $\mathbf{8}$, relating to the milling of the TiAlN-coated convex and concave inclined surfaces, the optimum levels in terms of the tool acceleration can be observed at A4 for $V_{\mathrm{c}}(140 \mathrm{~m} / \mathrm{min})$, B1 for $V_{\mathrm{f}}(358 \mathrm{~mm} / \mathrm{rev}), \mathrm{C} 1$ for $f_{\mathrm{p}}(0.8 \mathrm{~mm})$ and $\mathrm{D} 1$ (DMR) for the tool-path style.

In the machining of inclined surfaces, as seen in Figures $\mathbf{3}$ to $\mathbf{8}$, the tool-acceleration values decreased slightly with an increase of $V_{\mathrm{c}}$, in line with the data from references ${ }^{4,18,21}$. The literature emphasizes that a slight increase in $V_{\mathrm{c}}$ is caused by the following reasons: deformations of the main cutting edge of the cutting tool increase with a decrease in $V_{\mathrm{c}}$, and this causes an increase in the contact length between the cutting tool and

Table 3: ANOVA of the tool acceleration for inclined surface types

\begin{tabular}{|c|c|c|c|c|c|c|}
\hline Source of variance & $\mathrm{DOF}, v$ & SS & Variance, $V$ & $F$ ratio $(\alpha=5 \%)$ & $p$ & $P C R(\%)$ \\
\hline \multicolumn{7}{|c|}{ Convex inclined surface (TiC) } \\
\hline Cutting velocity, $V_{\mathrm{c}}(\mathrm{m} / \mathrm{min})$ & 3 & 0.0050203 & 0.0016734 & 5.92 & 0.049 & 11.70 \\
\hline Feed rate, $V_{\mathrm{f}}(\mathrm{m} / \mathrm{rev})$ & 3 & 0.0092032 & 0.0030677 & 10.85 & 0.041 & 21.50 \\
\hline Step over, $f_{\mathrm{p}}(\mathrm{mm})$ & 3 & 0.0255268 & 0.0085089 & 30.09 & 0.010 & 59.60 \\
\hline Tool-path style & 3 & 0.0022432 & 0.0007477 & 2.64 & 0.223 & 5.20 \\
\hline Error, $e$ & 3 & 0.0008483 & 0.0002828 & & & 2.00 \\
\hline Total & 15 & 0.0428417 & & & & 100.00 \\
\hline \multicolumn{7}{|c|}{ Concave inclined surface (TiC) } \\
\hline Cutting velocity, $V_{\mathrm{c}}(\mathrm{m} / \mathrm{min})$ & 3 & 26.015 & 8.672 & 1.84 & 0.050 & 13.63 \\
\hline Feed rate, $V_{\mathrm{f}}(\mathrm{m} / \mathrm{rev})$ & 3 & 21.613 & 7.204 & 1.53 & 0.048 & 11.32 \\
\hline Step over, $f_{\mathrm{p}}(\mathrm{mm})$ & 3 & 120.608 & 40.203 & 8.52 & 0.036 & 63.19 \\
\hline Tool-path style & 3 & 8.455 & 2.818 & 0.6 & 0.659 & 4.43 \\
\hline Error, $e$ & 3 & 14.148 & 4.716 & & & 7.41 \\
\hline Total & 15 & 190.839 & & & & 100.00 \\
\hline \multicolumn{7}{|c|}{ Convex inclined surface (TiN) } \\
\hline Cutting velocity, $V_{\mathrm{c}}(\mathrm{m} / \mathrm{min})$ & 3 & 0.002192 & 0.0007307 & 3.54 & 0.490 & 10.99 \\
\hline Feed rate, $V_{\mathrm{f}}(\mathrm{m} / \mathrm{rev})$ & 3 & 0.002838 & 0.0009461 & 4.58 & 0.042 & 14.23 \\
\hline Step over, $f_{\mathrm{p}}(\mathrm{mm})$ & 3 & 0.014166 & 0.0047221 & 22.88 & 0.014 & 71.03 \\
\hline Tool-path style & 3 & 0.000126 & 0.0000419 & 0.2 & 0.888 & 0.63 \\
\hline Error, $e$ & 3 & 0.000619 & 0.0002064 & & & 3.1 \\
\hline Total & 15 & 0.019941 & & & & 100.00 \\
\hline \multicolumn{7}{|c|}{ Concave inclined surface (TiN) } \\
\hline Cutting velocity, $V_{\mathrm{c}}(\mathrm{m} / \mathrm{min})$ & 3 & 0.006494 & 0.002165 & 0.44 & 0.048 & 3.22 \\
\hline Feed rate, $V f(\mathrm{~m} / \mathrm{rev})$ & 3 & 0.04115 & 0.013717 & 2.81 & 0.040 & 20.42 \\
\hline Step over, $f_{\mathrm{p}}(\mathrm{mm})$ & 3 & 0.133717 & 0.044572 & 9.14 & 0.021 & 66.37 \\
\hline Tool-path style & 3 & 0.005465 & 0.001822 & 0.37 & 0.780 & 2.71 \\
\hline Error, $e$ & 3 & 0.014633 & 0.004878 & & & 7.26 \\
\hline Total & 15 & 0.20146 & & & & 100.00 \\
\hline \multicolumn{7}{|c|}{ Convex inclined surface (TiAlN) } \\
\hline Cutting velocity, $V_{\mathrm{c}}(\mathrm{m} / \mathrm{min})$ & 3 & 0.005747 & 0.001916 & 1.42 & 0.050 & 15.07 \\
\hline Feed rate, $V_{\mathrm{f}}(\mathrm{m} / \mathrm{rev})$ & 3 & 0.009267 & 0.003089 & 2.29 & 0.045 & 24.3 \\
\hline Step over, $f_{\mathrm{p}}(\mathrm{mm})$ & 3 & 0.017734 & 0.005911 & 4.37 & 0.028 & 46.51 \\
\hline Tool-path style & 3 & 0.00132 & 0.00044 & 0.33 & 0.809 & 3.46 \\
\hline Error, $e$ & 3 & 0.004055 & 0.001352 & & & 10.63 \\
\hline Total & 15 & 0.038123 & & & & 100.00 \\
\hline \multicolumn{7}{|c|}{ Concave inclined surface (TiAlN) } \\
\hline Cutting velocity, $V_{\mathrm{c}}(\mathrm{m} / \mathrm{min})$ & 3 & 0.005838 & 0.001946 & 5.53 & 0.047 & 6.37 \\
\hline Feed rate, $V_{\mathrm{f}}(\mathrm{m} / \mathrm{rev})$ & 3 & 0.020738 & 0.006913 & 19.63 & 0.018 & 22.63 \\
\hline Step over, $f_{\mathrm{p}}(\mathrm{mm})$ & 3 & 0.059669 & 0.01989 & 56.49 & 0.004 & 65.12 \\
\hline Tool-path style & 3 & 0.004318 & 0.001439 & 4.09 & 0.139 & 4.71 \\
\hline Error, $e$ & 3 & 0.001056 & 0.000352 & & & 1.15 \\
\hline Total & 15 & 0.091619 & & & & 100.00 \\
\hline
\end{tabular}


the workpiece. The longer contact length between the cutting tool and the workpiece increases the friction force on the cutting-tool rake face and this leads to an increase in the tool acceleration depending on the cutting forces. ${ }^{4,21}$ The chip cross-sectional area generated by $f_{p}$ and $V_{f}$ is the most influential factor in determining the tool acceleration. As the $f_{p}$ and $V_{f}$ values increase, the tool acceleration increases as seen in Figures $\mathbf{3}$ to $\mathbf{8}$.

\subsection{Analysis of variance}

A statistical analysis of variance (ANOVA) was performed to examine, which cutting parameters were statistically significant for the tool acceleration. The $p$ values of ANOVA for all the cutting parameters and tool-path styles are shown at a significance level of $95 \%$ (Table 3). Thus, it can be stated that the differences between the measured values meaningfully result from the differences between the levels. ${ }^{5}$

For the response value of the tool acceleration (Table 4) of the TiC-coated cutter, the most significant parameters were $f_{\mathrm{p}}(p=0.010), V_{\mathrm{f}}(\mathrm{p}=0.041)$ and $V_{\mathrm{c}}(\mathrm{p}=0.049)$ when machining the convex inclined surfaces. Similarly, in the machining of the concave inclined surfaces, $f_{\mathrm{p}}, V_{\mathrm{f}}$ and $V_{\mathrm{c}}$ were again the significant parameters with the $\mathrm{p}_{\mathrm{p}}$ values of $0.036,0.048$ and 0.05 , respectively. For the cutting-force values of the TiN-coated cutter, $f_{\mathrm{p}}(\mathrm{p}=$ $0.014), V_{\mathrm{f}}(\mathrm{p}=0.042)$ and $V_{\mathrm{c}}(p=0.049)$ were significant parameters when machining the convex inclined surfaces. Likewise, $f_{\mathrm{p}}, V_{\mathrm{f}}$ and $V_{\mathrm{c}}$ were the most significant control factors with the $p$ values of $0.021,0.04$ and 0.048 when machining the concave inclined surfaces. Lastly, for the cutting-force values of the TiAlN-coated cutter, $f_{\mathrm{p}}$ $(p=0.028), V_{\mathrm{f}}(p=0.045)$ and $V_{\mathrm{c}}(p=0.05)$ were the most significant control factors when machining the convex inclined surfaces. Similarly, when machining the concave inclined surfaces with the TiAlN-coated cutter, $f_{\mathrm{p}}, V_{\mathrm{f}}$ and $V_{\mathrm{c}}$ were the most significant control factors with the $p$ values of $0.004,0.018$ and 0.047 , respectively. According to the response values of the tool acceleration (Table 3), when machining both convex and concave inclined surfaces with the TiC-, TiN- and TiAlN-coated cutters, the most significant control factors were $f_{\mathrm{p}}, V_{\mathrm{f}}$ and $V_{\mathrm{c}}$. It is worth mentioning that $f_{\mathrm{p}}$ was superior to $V_{\mathrm{f}}$ in all the cases.

\subsection{Determination of the optimum machining parame- ters and confirmation experiments}

The optimum parameters in machining convex inclined surfaces were $A 4 B 1 C 1 D 1$ for the TiC-coated cutter; $A 4 B 1 C 1 D 1$ for the TiN-coated cutter; and $A 4 B 1 C 1 D 3$ for the TiAlN-coated cutter. On the other hand, in terms of the tool acceleration, the optimum parameters in machining concave inclined surfaces were $A 4 B 1 C 1 D 4$ for the TiC-coated cutter; $A 4 B 1 C 1 D 1$ for the TiN-coated cutter; and $A 4 B 1 C 1 D 1$ for the TiAlN-coated cutter. By making a prediction considering the para- meters, the results can be calculated in advance using Equations (3) to (4) (Table 4): ${ }^{8}$

$$
\begin{aligned}
& \eta_{\text {cal }}=\bar{\eta}_{\mathrm{m}}+\left(\operatorname{Max} \frac{S}{N_{1}}-\bar{\eta}_{\mathrm{m}}\right)+\left(\operatorname{Max} \frac{S}{N_{2}}-\bar{\eta}_{\mathrm{m}}\right)+ \\
& +\left(\operatorname{Max} \frac{S}{N_{3}}-\bar{\eta}_{\mathrm{m}}\right)+\left(\operatorname{Max} \frac{S}{N_{4}}-\bar{\eta}_{\mathrm{m}}\right)
\end{aligned}
$$

where $\eta_{\text {cal }}$ is the calculated $S / N$ ratio under the optimum machining conditions; $\bar{\eta}_{\mathrm{m}}$ is the arithmetic mean of the $\mathrm{S} / \mathrm{N}$ ration of the studied surface form.

$$
A c c_{\text {cal }}=10^{-\frac{\eta_{\text {cal }}}{20}}
$$

$A c c_{\text {cal }}$ is the calculated base quantity; $\eta_{\text {cal }}$ is the calculated $S / N$ ratio.

Table 4: Calculated values for convex and concave inclined surfaces

\begin{tabular}{|c|c|c|c|c|}
\hline \multirow{2}{*}{ Coatings } & \multicolumn{2}{|c|}{$\begin{array}{c}\text { Convex inclined } \\
\text { surface }\end{array}$} & \multicolumn{2}{c|}{$\begin{array}{c}\text { Concave inclined } \\
\text { surface }\end{array}$} \\
\cline { 2 - 5 } & $\eta_{\text {cal }}(\mathrm{dB})$ & $\begin{array}{c}A c c_{\text {cal }} \\
\left(\mathrm{m} / \mathrm{s}^{2} \text { peak }\right)\end{array}$ & $\eta_{\text {cal }}(\mathrm{dB})$ & $\begin{array}{c}A c c_{\text {cal }} \\
\left(\mathrm{m} / \mathrm{s}^{2} \text { peak }\right)\end{array}$ \\
\hline TiC & 20.727 & 0.092 & 20.915 & 0.090 \\
\hline TiN & 19,337 & 0.108 & 13.722 & 0.206 \\
\hline TiAlN & 14.991 & 0.178 & 14.379 & 0.191 \\
\hline
\end{tabular}

Two test trails for each coating type at the optimalcontrol-factor settings were conducted as confirmation experiments. The tests were carried out with new cutters, one for each coating type in order to prevent undesirable effects caused by worn cutting tools..$^{5}$ The results of the experiments are presented in Table 5, showing the acceleration values $\left(A c c_{\text {mea }}\right)$ and $S / N$ ratios $\left(\eta_{\text {mea }}\right)$.

\begin{tabular}{|c|c|c|c|c|c|}
\hline & $\begin{array}{l}\text { Exp. } \\
\text { No. }\end{array}$ & $\begin{array}{c}\text { Accele- } \\
\text { ration } \\
\left(\mathrm{m} / \mathrm{s}^{2} \text { peak }\right)\end{array}$ & $\begin{array}{c}\text { Accele- } \\
\text { ration mea } \\
\left(\mathrm{m} / \mathrm{s}^{2} \text { peak }\right)\end{array}$ & $\begin{array}{l}\text { Accele- } \\
\text { ration } \\
\left(\eta_{\text {mea }}, \mathrm{dB}\right)\end{array}$ & \begin{tabular}{|c|} 
Absolute \\
differences \\
$(\%)^{*}$
\end{tabular} \\
\hline \multicolumn{6}{|c|}{ Convex inclined surface } \\
\hline \multirow{2}{*}{$\mathrm{TiC}$} & 1 & 0.086 & \multirow{2}{*}{0.090} & \multirow{2}{*}{20.906} & \multirow{2}{*}{0.2} \\
\hline & 2 & 0.094 & & & \\
\hline \multirow{2}{*}{ TiN } & 1 & 0.091 & \multirow{2}{*}{0.101} & \multirow{2}{*}{19.871} & \multirow{2}{*}{0.7} \\
\hline & 2 & 0.111 & & & \\
\hline \multirow{2}{*}{ TiAlN } & 1 & 0.153 & \multirow{2}{*}{0.172} & \multirow{2}{*}{15.236} & \multirow{2}{*}{0.6} \\
\hline & 2 & 0.191 & & & \\
\hline \multicolumn{6}{|c|}{ Concave inclined surface } \\
\hline \multirow{2}{*}{$\mathrm{TiC}$} & 1 & 0.101 & \multirow{2}{*}{0.103} & \multirow{2}{*}{19.741} & \multirow{2}{*}{1.3} \\
\hline & 2 & 0.105 & & & \\
\hline \multirow{2}{*}{$\mathrm{TiN}$} & 1 & 0.202 & \multirow{2}{*}{0.203} & \multirow{2}{*}{13.849} & \multirow{2}{*}{0.3} \\
\hline & 2 & 0.204 & & & \\
\hline \multirow{2}{*}{ TiAlN } & 1 & 0.179 & \multirow{2}{*}{0.188} & \multirow{2}{*}{14.506} & \multirow{2}{*}{0.3} \\
\hline & 2 & 0.197 & & & \\
\hline
\end{tabular}

Table 5: Comparison between confirmatory-test results and calculated values for convex and concave inclined surfaces

$* \frac{A c c_{\mathrm{cal}}-A c c_{\text {mea }}}{A c c_{\text {mea }}} \times 100$ 
A. GÖK et al.: EFFECTS OF CUTTING PARAMETERS AND TOOL-PATH STRATEGIES ON TOOL ACCELERATION ...

\subsection{Confidence interval}

Estimating the mean is only a point estimate based on the average of the results obtained from the experiment. It gives a $50 \%$ chance of being greater or lower than the mean. ${ }^{22}$ Therefore, confidence interval (CI) should be calculated. A confidence interval includes the maximum and minimum value between which the true average should be at some stated percentage of confidence. Confidence interval is used to verify the quality characteristics of confirmation experiments. The following formula is used to verify the predictions: ${ }^{23}$

$$
C I=\sqrt{F_{0.05}\left(1, v_{e}\right) V_{e}\left(\frac{1}{n_{\mathrm{eff}}}+\frac{1}{r}\right)}
$$

Where $F_{0.05}\left(1, v_{\mathrm{e}}\right)$ is the $F$ ratio at a $95 \%$ confidence $^{24}$ against degree of freedom 1 and the error of $v_{\mathrm{e}} ; V_{\mathrm{e}}$ is the error variance; $n_{\text {eff }}$ is the effective number of replication and is the number of test trials $(r=2)$.

$$
n_{\text {eff }}=\frac{N}{1+V_{\mathrm{T}}}
$$

where $N$ is the total number of experiments; $v_{\mathrm{T}}$ is the total main factor of degrees of freedom $\left(V_{\mathrm{T}}=12\right)$. The confidence-interval (CI) values for the convex and concave inclined surfaces obtained using Equations (5) and (6) are provided in Table 6.

Table 6: CI values

\begin{tabular}{|c|c|c|c|}
\hline \multirow{2}{*}{} & \multicolumn{3}{|c|}{ Tool acceleration $\left(\mathrm{m} / \mathrm{s}^{2}\right.$ peak) } \\
\cline { 2 - 4 } & TiC & TiN & TiAlN \\
\hline Convex inclined surface & 0.047 & 0.023 & 0.062 \\
\hline Concave inclined surface & 2.027 & 0.120 & 0.061 \\
\hline
\end{tabular}

The $\mathrm{S} / \mathrm{N}$ ratio differences between the estimated values obtained using Equations (2) and (3), and the results obtained with the confirmation experiments are shown in Table 5. The differences appear to be the smallest at a confidence-interval value of $5 \%$ given in Table 6. Therefore, both inclined surfaces and all the coatings used are confirmed as safe, having the optimal control-factor settings.

\subsection{Prediction of the tool acceleration}

A tool-acceleration prediction model based on the cutting-parameter values was developed using the response-surface methodology (RSM). The RSM is a methodology that uses a combination of statistical and mathematical techniques for the development and optimization of processes. The RSM optimizes (maximizes, minimizes or makes nominal) the response using a polynomial model of the first order or second order. ${ }^{5}$ As a result of the machinability experiments conducted, a first-order model and a quadratic polynomial tool-acceleration model depending on the values of $V_{\mathrm{c}}, V_{\mathrm{f}}$ and $f_{\mathrm{p}}$ were obtained as shown in Equation (7):

$$
\begin{gathered}
R M S=k_{0}+k_{1} \cdot V_{\mathrm{C}}+k_{2} \cdot V_{\mathrm{f}}+k_{3} \cdot f_{\mathrm{p}} \\
R M S=k_{0}+k_{1} \cdot V_{\mathrm{C}}+k_{2} \cdot V_{\mathrm{f}}+k_{3} \cdot f_{\mathrm{p}}+k_{4} \cdot V_{\mathrm{C}}^{2}+ \\
+k_{5} \cdot V_{\mathrm{f}}^{2}+k_{6} \cdot f_{\mathrm{p}}^{2}+k_{7} \cdot V_{\mathrm{C}} \cdot V_{\mathrm{f}}+k_{8} \cdot V_{\mathrm{C}} \cdot f_{\mathrm{p}}+k_{9} \cdot V_{\mathrm{f}} \cdot f_{\mathrm{p}}
\end{gathered}
$$

\begin{tabular}{|c|c|c|c|c|c|c|c|}
\hline \multirow{3}{*}{$\begin{array}{c}\text { Coeffi- } \\
\text { cient }\end{array}$} & \multirow{3}{*}{$\begin{array}{l}\text { Multi- } \\
\text { plier }\end{array}$} & \multicolumn{6}{|c|}{ Regression coefficients } \\
\hline & & \multicolumn{3}{|c|}{$\begin{array}{l}\text { Convex inclined } \\
\text { surface }\end{array}$} & \multicolumn{3}{|c|}{$\begin{array}{c}\text { Concave inclined } \\
\text { surface }\end{array}$} \\
\hline & & $\mathrm{TiC}$ & $\mathrm{TiN}$ & TiAlN & $\mathrm{TiC}$ & TiN & TiAlN \\
\hline$k_{0}$ & Sabit & 0.195 & 0.183 & 0.197 & 0.533 & 0.376 & 0.344 \\
\hline$k_{1}$ & $V_{\mathrm{c}}$ & -0.025 & -0.011 & -0.020 & -0.099 & -0.025 & -0.022 \\
\hline$k_{2}$ & $V_{\mathrm{f}}$ & 0.023 & 0.013 & 0.029 & 0.095 & 0.059 & 0.021 \\
\hline$k_{3}$ & $f_{\mathrm{p}}$ & 0.051 & 0.037 & 0.042 & 0.183 & 0.116 & 0.078 \\
\hline & \multicolumn{6}{|c|}{ Correlation coefficients } \\
\hline & & 89.19 & 88.80 & 86.26 & 85.77 & 83.48 & 83.72 \\
\hline
\end{tabular}

The values of the polynomial and first-order model regression coefficients and the correlation coefficient for the mathematical model of $R_{\mathrm{a}}$ are given in Tables $\mathbf{7}$ and $\mathbf{8}$.

\begin{tabular}{|c|c|c|c|c|c|c|c|}
\hline \multirow{3}{*}{$\begin{array}{c}\text { Coeffi- } \\
\text { cient }\end{array}$} & \multirow{3}{*}{$\begin{array}{l}\text { Multi- } \\
\text { plier }\end{array}$} & \multicolumn{6}{|c|}{ Regression coefficients } \\
\hline & & \multicolumn{3}{|c|}{$\begin{array}{l}\text { Convex inclined } \\
\text { surface }\end{array}$} & \multicolumn{3}{|c|}{$\begin{array}{c}\text { Concave inclined } \\
\text { surface }\end{array}$} \\
\hline & & $\mathrm{TiC}$ & TiN & TiAlN & $\mathrm{TiC}$ & TiN & TiAlN \\
\hline kO & Sabit & 0.205 & 0.206 & 0.217 & 0.534 & 0.322 & 0.333 \\
\hline$k 1$ & $V_{\mathrm{c}}$ & -0.037 & -0.015 & -0.024 & -0.166 & -0.005 & -0.043 \\
\hline$k 2$ & $V_{\mathrm{f}}$ & 0.016 & 0.010 & 0.030 & 0.132 & 0.063 & 0.017 \\
\hline$k 3$ & $F_{\mathrm{p}}$ & 0.045 & 0.030 & 0.025 & 0.181 & 0.060 & 0.037 \\
\hline$k 4$ & $V_{\mathrm{c}} \times V_{\mathrm{c}}$ & -0.028 & -0.020 & -0.022 & -0.010 & 0.012 & -0.005 \\
\hline$k 5$ & $V_{\mathrm{f}} \times V_{\mathrm{f}}$ & 0.002 & -0.009 & -0.018 & 0.023 & 0.055 & 0.000 \\
\hline k6 & $f_{\mathrm{p}} \times f_{\mathrm{p}}$ & 0.057 & -0.012 & 0.000 & -0.014 & 0.015 & 0.014 \\
\hline$k 7$ & $V_{\mathrm{c}} \times V_{\mathrm{f}}$ & -0.010 & -0.012 & -0.029 & -0.004 & -0.096 & -0.070 \\
\hline$k 8$ & $V_{\mathrm{c}} \times f_{\mathrm{p}}$ & -0.008 & -0.004 & 0.002 & 0.082 & 0.000 & -0.027 \\
\hline$k 9$ & $V_{\mathrm{f}} \times f_{\mathrm{p}}$ & -0.017 & -0.006 & -0.006 & -0.125 & 0.031 & 0.000 \\
\hline & \multicolumn{6}{|c|}{ Correlation coefficients } \\
\hline & & 91.79 & 94.54 & 90.57 & 92.13 & 97.04 & 85.29 \\
\hline
\end{tabular}

Table 7: First-order-model coefficients and correlation coefficients

Table 8: Polynomial-regression coefficients and correlation coefficients

The correlation coefficients for the convex inclined surface were $91.79,94.54$ and $90.57 \%$ for the $\mathrm{TiC}, \mathrm{TiN}$, and TiAlN coatings, respectively. On the other hand, the related coefficients for the concave inclined surface were 92.13, 97.04 and $85.29 \%$ for the coatings of $\mathrm{TiC}$, $\mathrm{TiN}$ and TiAlN, respectively. The values indicate that the model generated is successful at predicting the tool-acceleration values for both inclined surfaces.

\subsection{Optimization of the response}

One of the most important aims of the experiments related to manufacturing is to achieve the desired tool acceleration of the optimal cutting parameters. ${ }^{9}$ To this end, the response-surface optimization is the ideal technique for determining the tool acceleration in ball-end milling. Here, the goal is to minimize the tool acceleration. The RSM-optimization result for the acceleration parameter for the convex inclined surface and the $\mathrm{TiC}$ 
MATERIALI IN TEHNOLOGIJE/MATERIALS AND TECHNOLOGY (1967-2017) - 50 LET/50 YEARS

A. GÖK et al.: EFFECTS OF CUTTING PARAMETERS AND TOOL-PATH STRATEGIES ON TOOL ACCELERATION ...

Table 9: Response optimization for tool-acceleration-parameter components

\begin{tabular}{|c|c|c|c|c|c|c|c|c|c|}
\hline \multirow{2}{*}{ Parameter } & \multirow{2}{*}{ Goal } & \multicolumn{3}{|c|}{ Optimum combination } & \multirow[t]{2}{*}{ Lower } & \multirow[t]{2}{*}{ Target } & \multirow[t]{2}{*}{ Upper } & \multirow[t]{2}{*}{$\begin{array}{c}\text { Pre. } \\
\text { response }\end{array}$} & \multirow[t]{2}{*}{$\begin{array}{c}\text { Desira- } \\
\text { bility }\end{array}$} \\
\hline & & $V_{\mathrm{c}}(\mathrm{mm} / \mathrm{min})$ & $V_{\mathrm{f}}(\mathrm{m} / \mathrm{rev})$ & $f_{\mathrm{p}}(\mathrm{mm})$ & & & & & \\
\hline \multicolumn{10}{|l|}{ Convex surface, $\mathrm{TiC}$} \\
\hline Acceleration $\left(\mathrm{m} / \mathrm{s}^{2}\right.$ peak $)$ & Min. & 100 & 223 & 0.8 & 0.125 & 0.125 & 0,292 & 0.119 & 1 \\
\hline \multicolumn{10}{|l|}{ Convex surface, TiN } \\
\hline Acceleration $\left(\mathrm{m} / \mathrm{s}^{2}\right.$ peak $)$ & Min. & 130 & 318 & 0.8 & 0.117 & 0.117 & 0.239 & 0.116 & 1 \\
\hline \multicolumn{10}{|l|}{ Convex surface, TiAlN } \\
\hline Acceleration (m/s² peak) & Min. & 140 & 350 & 0.8 & 0.103 & 0.103 & 0.286 & 0.112 & 1 \\
\hline \multicolumn{10}{|l|}{ Concave surface, $\mathrm{TiC}$} \\
\hline Acceleration $\left(\mathrm{m} / \mathrm{s}^{2}\right.$ peak $)$ & Min. & 100 & 223 & 0.8 & 0.287 & 0.287 & 0.637 & 0.249 & 1 \\
\hline \multicolumn{10}{|l|}{ Concave surface, TiN } \\
\hline Acceleration $\left(\mathrm{m} / \mathrm{s}^{2}\right.$ peak $)$ & Min. & 130 & 318 & 0.8 & 0.254 & 0.254 & 0.471 & 0.226 & 1 \\
\hline \multicolumn{10}{|l|}{ Concave surface, TiAlN } \\
\hline Acceleration $\left(\mathrm{m} / \mathrm{s}^{2}\right.$ peak $)$ & Min. & 140 & 350 & 0.8 & 0.241 & 0.241 & 0.465 & 0.222 & 1 \\
\hline
\end{tabular}

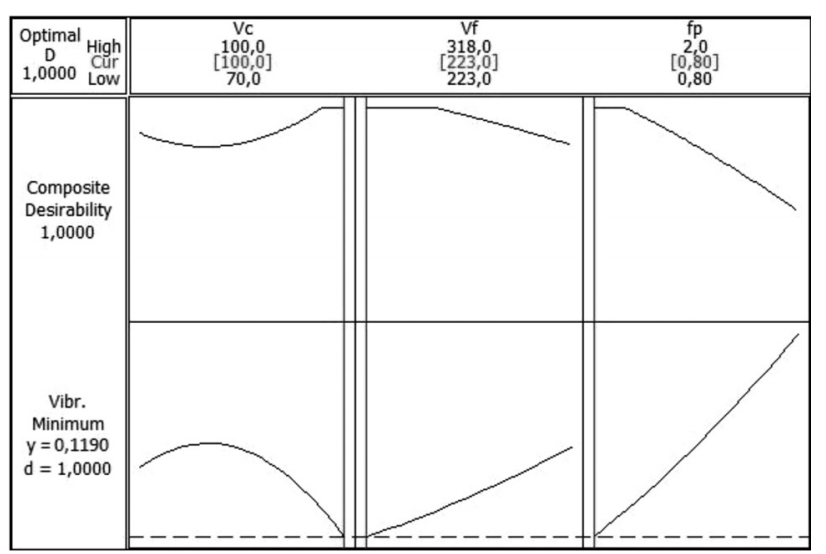

Figure 9: Response-optimization plot for the tool-accelerationparameter components for the convex surface and $\mathrm{TiC}$ coating

coating is shown in Figure 9. The optimum cutting parameters obtained for all the surface types and all the coatings are shown in Table 9.

\section{CONCLUSIONS}

The tool acceleration in a ball-end-milling process with cutting parameters and different tool-path strategies was measured, along with the orthogonal array, during the experiments. The results obtained are as follows:

- Both the Taguchi and response-surface statistical analyses indicated that the main effect of the step over is the most significant factor for the tool acceleration.

- According to the confirmation experiments under the optimal conditions, the measured tool-acceleration values for the convex inclined surfaces were found to be smaller than those of the calculated tool-acceleration values. On the other hand, for the concave inclined surfaces, the measured tool-acceleration values were found to be larger than those of the calculated tool-acceleration values. Nevertheless, the absolute difference in the percentile of the measured and calculated values was not more than 3.57 for both inclined surface types.

- The tool-acceleration values obtained for the machining of the convex inclined surfaces were found to be smaller in comparison to the values obtained for the machining of the concave inclined surfaces (Table 3). This is because the chip was comfortably removed from the cutting zone of the convex inclined surface. Besides, the cutting tool affects the inner surface and the contacts with the workpiece, resulting in a longer cutting edge during the tool acceleration.

- The tool-acceleration values for the contouring toolpath style were found to be smaller than those for the ramping tool-path style (Figures 3 to 8 ). This is because the contouring tool-path style causes movements parallel to the axis of the inclined surface. Previous studies support the finding that the movements made in parallel to the surface axis are ideal to move the chips away.

- The RSM was found to be effective for the identification and development of the significant relationships between the cutting parameters.

- The highest correlation coefficients were obtained with the tool-acceleration prediction model. The prediction model can be employed in relative studies.

- The optimum combination of the cutting parameters for the response optimization of all surface types includes the values of the largest cutting velocity, the smallest step over and the feed rate.

\section{REFERENCES}

${ }^{1}$ A. Gok, A new approach to minimization of the surface roughness and cutting force via fuzzy TOPSIS, multi-objective grey design and RSA, Measurement,70 (2015), 100-109, doi:10.1016/j.measurement. 2015.03.037

${ }^{2}$ A. Gok, C. Gologlu, H. I. Demirci, M. Kurt, Determination of Surface Qualities on Inclined Surface Machining with Acoustic Sound Pressure, Strojniški vestnik - Journal of Mechanical Engineering, 58 (2012) 10, 587-597, doi:10.5545/sv-jme.2012.352 


\section{MATERIALI IN TEHNOLOGIJE/MATERIALS AND TECHNOLOGY (1967-2017) - 50 LET/50 YEARS}

\section{A. GÖK et al.: EFFECTS OF CUTTING PARAMETERS AND TOOL-PATH STRATEGIES ON TOOL ACCELERATION ...}

${ }^{3}$ M. C. Shaw, Metal cutting principles, Oxford Oxford University Press, 2nd Edition ed., 2005

${ }^{4}$ E. M. Trent, Metal Cutting, Elsevier Science, Butterworth-Heinemann, 4th Edition ed., 2016

${ }^{5}$ A. Gok, C. Gologlu, H. I. Demirci, Cutting parameter and tool path style effects on cutting force and tool deflection in machining of convex and concave inclined surfaces, Int J Adv Manuf Technol, 69 (2013) 5-8, 1063-1078, doi:10.1007/s00170-013-5075-x

${ }^{6}$ W. H. Yang, Y. S. Tarng, Design optimization of cutting parameters for turning operations based on the Taguchi method, Journal of Materials Processing Technology, 84 (1998) 1-3, 122-129, doi:10.1016/S0924-0136(98)00079-X

${ }^{7}$ M. Kurt, E. Bagci, Y. Kaynak, Application of Taguchi methods in the optimization of cutting parameters for surface finish and hole diameter accuracy in dry drilling processes, Int Journal of Adv Manuf Technol. 40 (2009) 5-6, 458-469, doi:10.1007/s00170007-1368-2

${ }^{8}$ C. Gologlu, N. Sakarya, The effects of cutter path strategies on surface roughness of pocket milling of 1.2738 steel based on Taguchi method, Journal of Materials Processing Technology, 206 (2008) 1-3, 7-15, doi:10.1016/j.jmatprotec.2007.11.300

${ }^{9}$ S. Neşeli, S. Yaldız, E. Türkeş, Optimization of tool geometry parameters for turning operations based on the response surface methodology, Measurement, 44 (2011) 3, 580-587, doi:10.1016/ j.measurement.2010.11.018

${ }^{10}$ İ. Asiltürk, S. Neşeli, Multi response optimisation of CNC turning parameters via Taguchi method-based response surface analysis, Measurement, 45 (2012) 4, 785-794, doi:10.1016/j.measurement. 2011.12.004

${ }^{11}$ M. M. Aguiar, A. E. Diniz, R. Pederiva, Correlating surface roughness, tool wear and tool vibration in the milling process of hardened steel using long slender tools, International Journal of Machine Tools and Manufacture, 68 (2013), 1-10, doi:10.1016/j.ijmachtools. 2013.01.002

${ }^{12}$ H. Wang, S. To, C. Y. Chan, Investigation on the influence of tool-tip vibration on surface roughness and its representative measurement in ultra-precision diamond turning, International Journal of Machine Tools and Manufacture, 69 (2013) 20-29, doi:10.1016/j.ijmachtools. 2013.02.006

${ }^{13}$ O. B. Abouelatta, J. Mádl, Surface roughness prediction based on cutting parameters and tool vibrations in turning operations, Journal of Materials Processing Technology, 118 (2001) 1-3, 269-277, doi:10.1016/S0924-0136(01)00959-1
${ }^{14}$ S. Orhan, A. O. Er, N. Camuşcu, E. Aslan, Tool wear evaluation by vibration analysis during end milling of AISI D3 cold work tool steel with 35 HRC hardness, NDT \& E International, 40 (2007) 2, 121-126, doi:10.1016/j.ndteint.2006.09.006

${ }^{15}$ B. W. Ikua, H. Tanaka, F. Obata, S. Sakamoto, Prediction of cutting forces and machining error in ball end milling of curved surfaces -I theoretical analysis, Precision Engineering, 25 (2001), 266-273, doi:10.1007/s00170-012-4012-8

${ }^{16}$ B. W. Ikua, H. Tanaka, F. Obata, S. Sakamoto, T. Kishi, T. Ishii, Prediction of cutting forces and machining error in ball end milling of curved surfaces -II experimental verification, Precision Engineering, 26 (2002), 69-82, doi:10.1007/s00170-012-4175-3

${ }^{17}$ G. M. Kim, B. H. Kim, C. N. Chu, Estimation of cutter deflection and form error in ball-end milling processes, International Journal of Machine Tools and Manufacture, 43 (2003) 9, 917-924, doi:10.1016/ S0890-6955(03)00056-7

${ }^{18}$ M. Günay, E. Yücel, Application of Taguchi method for determining optimum surface roughness in turning of high-alloy white cast iron, Measurement, 46 (2013) 2, 913-919, doi:10.1016/j.measurement.2012.10.013

${ }^{19}$ R. Landers, A. Ulsoy, Chatter analysis of machining systems with nonlinear force processes, ASME International mechanical engineering congress and exposition, 76 (1996), 183-190, doi:10.1016/ S0924-0136(01)00877-9

${ }^{20}$ M. C. Kathleen, Y. K. Natalia, R. Jeff, Response surface methodology, center for computational analysis of social and organizational systems (CASOS), CASOS Technical Report, http://www.casos.cs.cmu.edu/publications/papers/CMU-ISR-04-136. pdf, 19.05.2017

${ }^{21}$ M. Sarıkaya, A. Güllü, Taguchi design and response surface methodology based analysis of machining parameters in CNC turning under MQL, Journal of Cleaner Production, 65 (2014), 604-616, doi:10.1016/j.jclepro.2013.08.040

${ }^{22}$ D. Montgomery, Design and analysis of experiments, New York: Wiley, 2000

${ }^{23}$ M. Nalbant, H. Gökkaya, G. Sur, Application of Taguchi method in the optimization of cutting parameters for surface roughness in turning, Materials \& Design, 28 (2007) 4, 1379-1385, doi:10.1016/j.matdes.2006.01.008

${ }^{24}$ T. Ding, S. Zhang, Y. Wang, X. Zhu, Empirical models and optimal cutting parameters for cutting forces and surface roughness in hard milling of AISI H13 steel, Int J Adv Manuf Technol, 51 (2010) 1-4, 45-55, doi: 10.1007/s00170-010-2598-2 